\title{
Management ownership and market valuation
}

\section{Citation}

Morck, Randall, Andrei Shleifer, and Robert W. Vishny. 1988. “Management Ownership and Market Valuation." Journal of Financial Economics 20 (January): 293-315. doi:10.1016/0304-405x(88)90048-7. http://dx.doi.org/10.1016/0304-405X(88)90048-7.

\section{Published Version}

doi:10.1016/0304-405X(88)90048-7

\section{Permanent link}

http://nrs.harvard.edu/urn-3:HUL.InstRepos:29407535

\section{Terms of Use}

This article was downloaded from Harvard University's DASH repository, and is made available under the terms and conditions applicable to Other Posted Material, as set forth at http:// nrs.harvard.edu/urn-3:HUL.InstRepos:dash.current.terms-of-use\#LAA

\section{Share Your Story}

The Harvard community has made this article openly available.

Please share how this access benefits you. Submit a story.

Accessibility 
NBER Working Paper \#2055

October 1986

Management Ownership and Corporate Performance:

An Empirical Analysis

\section{ABSTRACT}

We investigate the relation between management ownership and corporate performance, as measured by robin's Q. In a cross-section of fortune $500 \mathrm{firms,}$ Tobin's $Q$ first increases and then declines as board of directors holdings rise. For older firms there is weak evidence that $Q$ is lower when a firm is run by a member of the founding family than when it is run by an officer unrelated to the founder.

Randa 11 Morck Department of Finance 4-210 Faculty of Business University of Alberta Edmonton, Alberta CANADA
Andrei Shleifer Department of Economics Princeton University Princeton, NJ 08544
Robert Vishny

Graduate School of Business

University of Chicago 1101 East 58th Street Chicago, IL 60637 


\section{Introduction}

Many large American corporations are not run by the people who own them. As stressed by Berle and Means (1932), when managers hold little equity in the firm and shareholders are too dispersed to enforce value-maximization, corporate assets may be deployed to benefit managers rather than shareholders. According to Jensen and Meckling (1976), these costs of deviation from value-maximization decline as management ownership rises. As their stakes rise, managers pay for a greater share of the costs of their on-the-job consumption 1 and are less likely to squander corporate wealth. According to this "convergence of interests" hypothesis, corporate performance improves with increases in management ownership. More recently, Demsetz (1983) and Fama and Jensen (1983) have pointed out offsetting costs of significant ownership by management. These writers recognized that, when a manager owns only a small stake, market discipline (e.g. the managerial labor market (Fama, 1980), the product market (Hart, 1983), and the market for corporate control (Jensen and Ruback, 1983)) may still force him toward value maximization. In contrast, a manager who controls a substantial fraction of his firm's equity may have enough voting power to guarantee his future employment with the firm at an attractive salary ${ }^{2}$. He may then indulge his tastes for on-the-job consumption, although perhaps to a more limited extent than if he had effective control of the firm but did not have any claim to its cash flows ${ }^{3}$. This "entrenchment" hypothesis predicts that performance declines as management's stake increases beyond the point where control challenges are still effective.

As the above discussion suggests, theoretical arguments alone cannot unambiguously predict the relationship between management ownership and corporate performance. While the "convergence of interests" hypothesis predicts a uni- 
formly positive relation, the "entrenchment" hypothesis predicts a decline in performance for sufficiently high management stakes. In this paper, we study the relation between managerial ownership and performance empirically.

In section 2, we look at the relation between two measures of the firm's performance (Tobin's $Q$ and profit rate) and the shareholdings of its board of directors. A related study was conducted by Demsetz and Lehn (1985), who estimated a linear relationship between profit rate and ownership by large shareholders (as opposed to just management), and found no correlation. We estimate a nonlinear relationship between management ownership and performance to capture the possible presence of both the "convergence of interests" and "entrenchment" effects. We also attempt to evaluate a number of reasons why the observed relationship might be spurious.

Section 3 takes a more disaggregated look at the relation between management ownership and performance. First, we segregate ownership by top corporate officers from that of other board members and evaluate the impact of ownership by these two distinct groups on performance. In part, this is done to address a frequently made claim that outside board members are puppets of top of $\mathrm{i}$ cers. Second, we evaluate the impact on corporate performance of having a founding family on the board of directors. We do this because we are interested in the possibility that a management team can become entrenched for reasons other than the number of voting shares it controls.

Section 4 summarizes our findings. 
2. The Relationship Between Board Ownership and Performance.

In this section, we evaluate the relationship between board ownership and performance in a sample of large industrial firms. For this purpose, we use a December, 1980 listing of the names and stakes of large shareholders of 456 of the Fortune 500 firms supplied by Corporate Data Exchange (CDE). The CDE identified shareholders who were members of the board of directors, with the exception of those whose stakes were below .2\%. While this means that, in large firms, positions worth millions of dollars are not reported, the CDE numbers are still very useful for examining issues of corporate control, since board members holding less than $.2 \%$ are never among our firms' largest shareholders.

To measure performance, we rely mainly on average Tobin's $Q$, equal to the ratio of the firm's market value to the replacement cost of its physical assets. Tobin's $Q$ is high when the firm has valuable intangible assets in addition to physical capital, such as monopoly power (Lindenberg and Ross, 1981), goodwill, a stock of patents, or good managers. While $Q$ is undoubtedly a very noisy signal of managerial performance, we believe that it is well-suited to our purpose. Because we are interested in the predictable effects of a firm's ownership structure on its value, it seems natural to look at the cross-sectional relation between ownership and value. One alternative might be to study events that represent large unexpected changes in ownership structure for which there is no accompanying news to contaminate the experiment. But large changes in ownership structure are fairly rare, except for those accompanying control challenges, where there is clearly much more going on. For this reason, we feel justified in concentrating on a cross-sectional analysis of measures such as $Q$ and the profit rate. 
The measure of $Q$ we employ was obtained from the Griliches $R$ \& $D$ master file (Cummins, Hall and Laderman, 1982) for 1980. The numerator of $Q$ is the firm's market value, defined as the sum of the actual market value of common stock and estimated market values of preferred stock and debt ${ }^{4}$. The denominator of $Q$ is the replacement cost of the firm's plant and inventories, $A$, also taken from the $R \& D$ master file. Values of $Q$ are not available for 85 firms, primarily because of difficulty in obtaining values of long term debt, and, in some cases, the replacement cost. A. While we cannot be sure that such sample selection does not bias our results, the omitted firms do not appear to be very different from the included ones in any observable respect ${ }^{5}$. Our final sample consists of 371 firms.

In this sample, the mean combined stake of a 11 board members is $10.6 \%$. The median stake, however, is on ly 3.46 , suggesting that the distribution is skewed. Indeed, in 103 firms (28\% of the sample), total board holdings added to no more than $1 \%$ of outstanding equity, and in 46 of our firms ( 128 of the sample), no board member owned more than $0.2 \%$ of the firm. Nonetheless, in $31 \%$ of our sample the board owned more than $10 \%$ of the firm; and in $20 \%$ of the sample the board owned more than $20 \%$ of the firm. These numbers accord with the findings of Lewellyn (1971) and Demsetz and Lehn (1985) who also document the prevalence of significant managerial ownership in the United States. These results also corroborate the hypothesis of Fama and Jensen (1983) that firms in which management owns over $50 \%$ of the equity (and thus has complete control) should have a hard time surviving as organizations. In fact, there are only 14 such firms in our sample 6 .

Table 1 presents means of $Q$ for different levels of the board's percentage 
ownership (the mean $Q$ in the sample is .85 , with a standard deviation of .67). It suggests that, at low levels of ownership, higher stakes are associated with higher Q's. It also records a decline of $Q$ for substantial ownership positions, although outliers strongly affect average $Q$ in some cells. In particular, the 35\%-40\% ownership cell includes Hewlett-Packard with $Q=3.21$ and Searle with $Q=1.72$, which together account for the mean $Q$ in that ce 11 being 1.06 . Similarly, Dow-Jones alone, with $Q=2.58$, accounts for the mean $Q$ of 1.46 in the 60-65\% cel1. While Table 1 suggests that the relationship between ownership and Q might be nonlinear, it also highlights the need for controlling for some sources of heterogeneity across firms, particularly industry.

In our econometric work, it would be impractical to use as many cells of ownership levels as appear in Table 1, primarily because of the scarcity of observations in some cells. Instead, we consider only four categories of ownership levels, and estimate regressions using dummies for these categories. Specifically, we define:

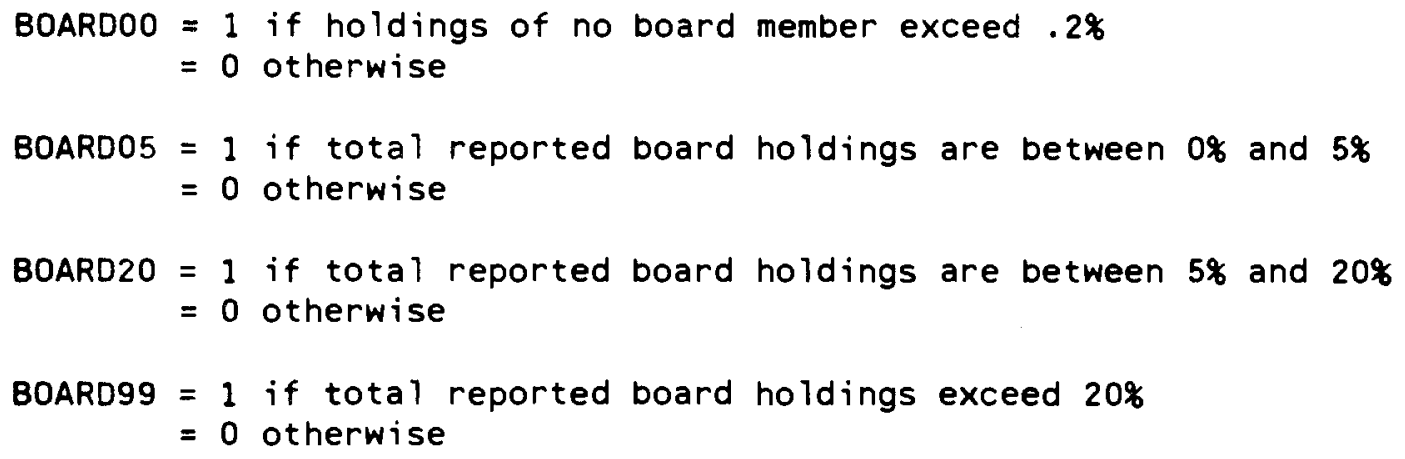

Partitioning ownership leve is at $0 \%, 5 \%$, and $20 \%$ can be justified as follows. Firms with close to no board ownership are probably a special group in which the convergence of interests effect might be the weakest, except for possible ownership-mimicking incentive contracts. The choice of $5 \%$ as the 
dividing line between low and moderate ownership is arbitrary, motivated primarily by the benefits of having a large number of observations in both the BOARDO5 and BOARD20 categories. The choice of $20 \%$ as the cutoff for high ownership stems from our prior belief that bona fide entrenchment should become important in the 20-30\% range (Weston, 1977), balanced against the need to have enough observations in that cell. Later in the paper, we consider alternative specifications.

The first column of Table 2 presents the regression of Tobin's $Q$ on the board dummies (BOARDOO is omitted). This regression is essentially equivalent to a comparison of means of $Q$ across ownership cells; the only differences from Table 1 are the coarser categorization and the calculation of White-consistent standard errors for the parameter estimates. The regression confirms the nonlinear pattern of Table 1 , with Q's first rising and then declining as board ownership rises. A simple comparison of means, however, runs into the problem of omitting other determinants of $Q$ that are correlated with board ownership. To deal with this problem, we estimate a model that explicitly incorporates variables that might be correlated with both ownership and $Q$.

The first type of controls we use are observable measures of intangible assets that affect $Q^{7}$. These are (divided by $A$, to make them compatible with Q):

- $R D / A-1980 R \& D$ expenditures (COMPUSTAT). - ADV/A - 1980 advertising expenditures (COMPUSTAT) ${ }^{8}$. In addition to observed assets, we consider several variables that might be correlated with unobserved intangible assets, as well as with board ownership: - D/A - the ratio of the calculated market value of a firm's long-term debt 
to A. This variable may in part capture the value of corporate tax shields. Alternatively, according to the pecking-order theory, debt is negatively correlated with the profitability of the firm, and hence with $Q$. Managers of the more leveraged firms might hold a higher fraction of equity, on average, for the same $Q$.

- A - replacement cost of assets. 'A' measures size; and unobserved intangible assets of a firm might be correlated with size. Also, it is hard to own a large part of a bigger firm, raising the possibility that a large board stake proxies for small firm size.

- SIC3 - three digit SIC code dummies, used to control for possible spurious correlation between ownership and $Q$ operating through industry effects (Demsetz and Lehn, 1985).

The final equation, hereafter equation (1), takes the form:

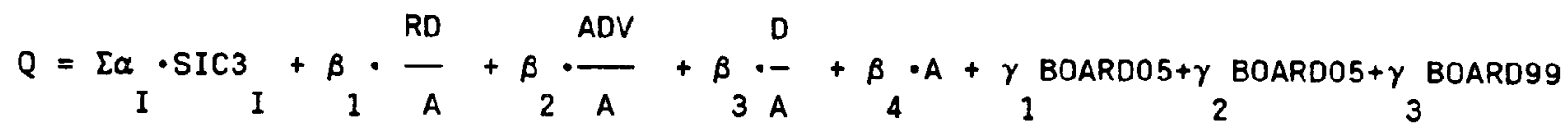

The estimated coefficients and their heteroskedasticity-consistent standard errors are shown in the second column of Table 2, while Table 3 presents t-statistics for the pairwise null hypotheses that the coefficients on the board ownership dummies are equal.

Tables 2 and 3 suggest that, all other things equal, firms in which management owns between $5 \%$ and $20 \%$ have the highest $Q^{\prime} s$, which exceed the $Q^{\prime} s$ of firms with negligible board ownership by $.206(t=3.06)$, the $Q$ 's of firms with negligible to $5 \%$ ownership by $.085(t=.91)$, and the $Q^{\prime}$ 's of firms with dominant ownership by $.13(t=1.61)$. The second best performing are firms with negligible 
to $5 \%$ ownership, whose Q's exceed those of firms with negligible ownership by $.201(t=2.77)$ and those of firms with dominant ownership by .045 $(t=.62)$. One interpretation of these findings is that the convergence of interests hypothesis is the key to understanding the data at lower ownership levels, while the entrenchment hypothesis is operative for large board ownership.

Some potential difficulties with these regressions concern 1) the arbitrariness of the specification, 2) the stability of results over time, 3) the effect of wealth constraints on managerial ownership, and 4) the omission of a measure of growth opportunities from the right hand side of equation (1). We presently address these issues.

To some extent, our choice of where to partition ownership cells is arbitrary. To judge the robustness of our results, we estimated equation (1) using different cutoff levels. In particular, in addition to separating low from moderate ownership at $5 \%$, we did so at $2.5 \%$ and at $7.5 \%$; and in addition to separating moderate from high ownership at $20 \%$, we did so at $15 \%$ and $25 \%$. The results of these regressions, with and without controlling for other variables, support the following conclusions ${ }^{9}$. If the range of low ownership is defined as either $0-2.5 \%$ or $0-5 \%$, then $Q^{\prime}$ s in the low ownership cell are significantly lower than Q's in the moderate ownership cel1 (i.e., 2.5-20\% or 5-20\%). However, there is no support for an increase in $Q$ as ownership rises from $7.5 \%$ to 20\%. Further, there is evidence of a significant decline in $Q$ as board ownership increases from somewhere between 15-20\% to about 25\%. The decline seems essentially complete when board ownership reaches $25 \%$.

Because we only have ownership data for 1980, the stability of our results over time is in question. As a crude test of stability, we obtained 1979 and 
1981 Q's for the firms in our 1980 sample, and ran the regression in the second column of Table 2 with $Q$ for 1979 and with $Q$ for 1981 as the dependent variables, but with 1980 values of all the independent variables. Because ownership is relatively stable over time, these regressions should be at least suggestive of the stability of our results over time. The results in fact are quite similar to the findings in Table 2.10

The next issue is the effect of wealth constraints on managerial ownership. If a management team is wealth constrained, it can only afford to own a large proportion of the equity if average $Q$, and hence the market value of the firm, is low. That is, the managers might only be able to afford to own a large stake in a poorly performing firm. This argument predicts that there will be a spurious negative correlation between the proportion of equity owned by the board and $Q$. It therefore only strengthens our finding of the positive correlation of $Q$ and ownership at lower ownership levels. On the other hand, this spurious negative correlation might account for our finding that $Q$ falls as board ownership becomes very large.

To subject this issue to some empirical scrutiny, consider the relation between board ownership and the replacement cost of the firm, A. Holding leverage constant, market value can be lower either because $Q$ is low or because the firm has fewer assets, i.e., A is low. If lower market value facilitates larger board ownership, we should see a negative correlation between replacement cost and the fraction of equity owned by the board. Table 4 presents the values of $A$ at various levels of board ownership. The relationship is not monotonic, especially in the range of high board ownership. For firms for which the board ownership is at least $5 \%$, the correlation between board ownership and $A$ is only 
-.02 . This correlation points against the view that size is a strong deterrent to management ownership. Although we cannot rule out the possibility that our finding of low Q's for firms with very high board ownership is spurious, evidence on the replacement cost of capital points against this possibility.

Our omission of measures of firm growth rates from $Q$ equations also raises some important issues. A high $Q$ may in part reflect the value of future growth opportunities of the firm. If managers own large stakes in younger, faster-growing firms which tend to have high Q's, then the positive association between board ownership and $Q$ that we observe might be spurious. On the other hand, given that fast growth is itself an important component of performance that depends on the actions of the management, we are probably understating the effect of management ownership on performance if we focus only on the effect of management ownership on $Q$ holding growth constant. That is, much of the variation in $Q$ across different board ownership structures may be due to the differing values of growth prospects that are achieved by managements with different incentives to maximize value. With this reservation in mind, we include the growth rate of the firm's labor force, GL 11, into the regression. The result is as follows:

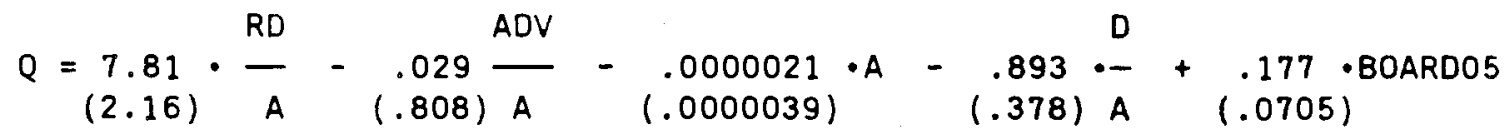

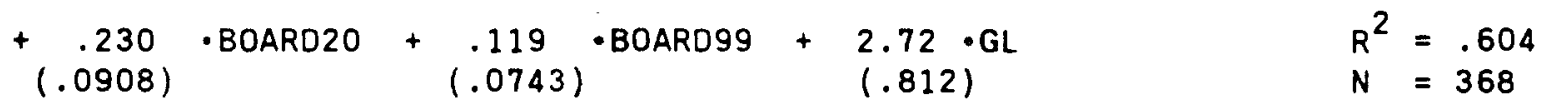

GL enters significantly into the regression and reduces somewhat the size and statistical significance of the other estimated coefficients. The basic pattern of increases and subsequent declines in Q's as ownership rises nonetheless 
remains, and the estimated coefficients on BOARD05 and BOARD20 are still significant at the $95 \%$ level.

Finally, we look at the profit rate as an alternative measure of performance. The profit rate is defined as the ratio of the firm's net cash flows (less the inflation-adjusted value of depreciation) to the previously defined replacement cost of its capital stock, A. The board ownership regressions which parallel those for Tobin's $Q$ are presented in the right panel of Table 2 . Although the qualitative pattern of the estimated coefficients on the ownership dummies is the same as in the $Q$ regressions, the statistical significance of the estimates is much lower. Only the estimated coefficient on BOARD20 is significant at the $95 \%$ level. The point estimate for BOARD20 implies that, all other things equal, firms with 5-20\% board ownership have profit rates .017 higher than those of firms with negligible board ownership, and .012 higher than those of firms with dominant board ownership. To gauge the magnitudes of these effects, note that the mean profit rate of the sample is .055 with a standard deviation of .035 .

The above results appear at odds with the finding of Demsetz and Lehn (1985) of no association between large shareholder ownership and performance. The important differences between our procedures seem to be twofold. First, we focus only on the equity stakes of the board of directors, while Demsetz and Lehn measure concentration of ownership weighting ownership by members of the board and by other large shareholders equally. To the extent that large shareholders without board seats represent competing managerial teams, they may be attracted to firms with poorly performing incumbent management. This selection effect would tend to reduce the observed correlation between ownership 
concentration and performance.

Second, Demsetz and Lehn estimate a linear relationship between ownership concentration and performance. When we estimate a linear relationship between the ir measure of performance (profit rate) and our board stake variable, we get

$$
\Pi=\frac{.055-.005}{(.002)(.014)} \cdot \text { BOARD, }
$$

which is consistent with the ir result. Even controlling for SIC codes and other factors in this regression does not yield a significant estimated coefficient on the board stake variable. We are led to conclude that Demsetz and Lehn's failure to find a relationship between ownership concentration and profitability may have been due to their use of a linear specification that does not capture what appears to be an important nonlinearity. 


\section{The Composition of the Board}

So far we have assumed that the impact of the board's ownership stake on performance is independent of who owns that stake. This might not always be appropriate, for at least two reasons. First, ownership by officers and by outside directors might have different effects. Second, at any given level of ownership, leadership by the firm's founders or by their descendants might have different effects on performance than leadership by officers who are not related to the founders. In this section, we examine these two hypotheses.

The distinction between officers and outside board members might be important for several reasons. While it is the fiduciary duty of all directors to represent the interests of shareholders, outside directors in particular must oversee the performance of the firm's officers. But monitoring the performance of top officers requires time and effort. In addition, an outside director serving on a board dominated by officers with more expertise and influence over votes, risks losing his position if he objects to these officers' choices. Without a personal financial interest in the firm or control over a large block of votes, an outside director may be reluctant to second guess poor corporate decisions. Presumably, the extent of the outside directors' role in disciplining officers is positively related to the equity stakes of the former.

For officers, the ownership stake is only a partial indicator of their interest in the financial success of the firm. Officers also get significant salaries, bonuses and incentive plans (Murphy, 1985) and may be subject to the discipline of the managerial labor market (Fama, 1980)12. In addition, top officers sometimes exercise virtually complete control over their firms with 
only small stakes, since their familiarity with the business and tenure with the firm enables them to dominate the board regardless of their personal equity ownership. These considerations suggest that the equity holdings of officers and outside board members might have different effects on performance.

Our analysis here parallels that of the previous section. By examining the 1980 annual reports of our 371 firms, we identified the two senior corporate officers of each firm. Returning to the CDE's listing of stock holdings, we constructed a new variable (OFFICER) giving the holdings of these top officers, who were usually the chairman and the president ${ }^{13}$. The holdings of the remainder of the board of directors are denoted OUTBOARO. That variable therefore includes the holdings of junior officers, such as vice-presidents. Since junior officers generally own very little stock, this classification is unlikely to make much difference.

The two top officers owned $6.3 \%$ of their firms on average. In $117 \mathrm{firms}$ ( $32 \%$ of our sample), however, their stake was negligible; and their median stake was approximately one half of one percent. In 60 firms $116 \%$ of our sample) their holdings were in excess of $10 \%$, and in 43 firms (12\% of our sample) their stake exceeded $20 \%$.

The mean value of the OUTBOARD variable was $4.4 \%$, with only 97 firms (26\% of the total) having negligible outside board ownership. The median for OUTBOARO was just under one percent, and was thus greater than that of the OFFICER variable. In 50 firms ( $13 \%$ of the sample) the outside board's holdings exceeded 10\%, and in 24 firms ( $6 \%$ of the sample), its stake surpassed $20 \%$.

Column 1 of Table 5 contains the results of regressions of $Q$ on ownership variables alone as in Column 1 of Table 2, but with a separate set of dummy 
variables for the top two officers' stake and for the stake of the rest of the board. In Column 2 of Table 5, we report the results of controlling for industry effects and other determinants of $Q$. Although the pattern of point estimates in columns 1 and 2 is consistent with firm value being maximized at moderately high levels of ownership, the estimates are not reliable enough to draw any solid conclusions. Still, it is worth noting that the results for the outer board more closely resemble the results for the board as a whole than do the top officer results. The pattern of point estimates for top officer holdings may reflect the absence of significant unexploited gains from raising their holdings. This is not the case for outside board holdings. This difference is consistent with the importance of non-ownership-based compensation for top officers, but not for outside directors. It is also consistent with the argument that officers and free-riding shareholders will make it difficult for outside board members to profitably increase their stakes (Shleifer and Vishny, 1986).

In the previous discussion, we have explored share ownership as a means to managerial entrenchment. But managers can become entrenched even without control over a large block of votes, especially in firms where the founder is a top officer ${ }^{14}$. Since founders presumably have a special claim to control of their firms, they might be instrumental in selecting the board or otherwise become entrenched even with small stakes. At the same time, the entrepreneurial ability of the founder can be a valuable asset, at least early in the life of the firm.

To discriminate between firms in which the founding family might supply entrepreneurial talent, and firms in which such families might only reduce corporate wealth, we estimate different founder effects for old and young 
firms. In particular, we reestimate the Tobin's $Q$ regressions including a dummy variable that is equal to 1 if a member of the founding family15 is one of the top two officers and another dummy variable that is equal to 1 if the founding family is top management and the firm was first incorporated in 1950 or later 16. This specification aims to capture the impact of the founding family on the firm's performance independent of its stake. The results for the combined board holdings regression provide some confirmation of the expected founder effects:

$$
\begin{aligned}
& Q=\frac{8.22}{(2.31)} \cdot \frac{R D}{A}+\underset{(.803)}{.115} \cdot \frac{A D V}{A}-\frac{.910}{(.354)} \cdot \frac{D}{A}-\frac{.00000154}{(.00000396)} \cdot A \\
& +.196 \cdot \text { BOARDO5 }+.304 \cdot \text { BOARDO5 }+.177 \cdot \text { BOARD99 } \\
& (.0737) \quad(.0965) \quad(.0858) \\
& \begin{aligned}
.125 \\
(.0791)
\end{aligned} \text { FOUNDER }+\begin{array}{l}
.351 \\
(.167)
\end{array} \cdot \text { FOUNDER50 } \quad \begin{array}{l}
R^{2}=.598 \\
N=371
\end{array}
\end{aligned}
$$

For pre-1950 firms, the presence of the founding family at the top of the management team is associated with a Tobin's $Q$ that is .125 lower on average. However, the t-statistic for this difference is only -1.58 , so the result must be interpreted with caution. The estimated coefficient on FOUNDER50 indicates that the effect of the founding family on $Q$ is .351 greater in newer firms than it is in older firms. This difference is reliably different from zero with a t-statistic of 2.10. On the other hand, one cannot confidently conclude that the net effect of the founding family in newer firms (the sum of the two dummy coefficients), estimated to be .226 , is different from zero $(t=1.24)$.

Unfortunately, results for the regression in which we segregate the holdings of top officers and other board members are plagued by 
multicollinearity. For example, of the 40 firms with top officer stakes between 5 and 20\%, 31 have a founding family member as a top officer, and of the 43 firms with top officer stakes of more than 20\%, 38 have a founding family member as a top officer. Finally, these two groups account for 69 of the 88 firms with FOUNDER=1. The regression results are:

$$
\begin{aligned}
& Q=\frac{R .56}{(2.35)} \cdot \frac{R}{A}+\underset{(.828)}{.023} \cdot \frac{A D V}{A}-\underset{(.362)}{.930} \cdot \frac{D}{A}-\frac{.00000249}{(.00000389)} \cdot A \\
& +\underset{(.0688)}{.054} \cdot \text { OFFICERO5 }+\underset{(.116)}{.0048} \cdot \text { OFFICER20 }-\underset{(.121)}{.048} \cdot \text { OFFICER99 } \\
& +\underset{(.0648)}{.143} \cdot \text { OUTBOARD05 }+\underset{(.106)}{.225} \cdot \text { OUTBOARD20 }+\underset{(.101)}{.163} \cdot \text { OUTBOARD99 } \\
& \begin{aligned}
.027 \cdot \text { FOUNDER }+.324 \\
(.0942)
\end{aligned} \cdot \text { FOUNDER50 } \quad \begin{array}{l}
R^{2}=.598 \\
N=371
\end{array}
\end{aligned}
$$


4. Conclusion.

In this paper, we examined two well-known hypotheses concerning the impact of managerial ownership on a firm's performance. The "convergence of interests" hypothes is suggests that agency costs should fall, and performance should improve, as the management's stake rises. We found support for this hypothes is in the 0-10\% range of ownership by the board of directors, although our results seem to be driven more strongly by holdings of the outside board members than by holdings of top officers. The "entrenchment" hypothesis predicts a deciine of performance when managers are protected against the discipline of the market and are thus free to pursue their own objectives instead of value-maximization. We find evidence for this hypothesis based on lower levels of performance for firms with very large management holdings and on the finding that founding families have a negative impact on performance of older firms.

We cannot, however, rule out the possibility that our results can be explained by factors other than the "convergence of interests" and "entrenchment" hypotheses. Alternative explanations may have to do with the joint behavior of performance and management holdings over the corporate life-cycle, a spurious correlation between fraction of equity owned by management and market value induced by wealth constraints, or signalling hypotheses such as that of Leland and Pyle (1977). In addition, a theory predicting a nonlinear relationship beween management ownership and performance of the type that we have found has been proposed by Stulz (1986). In his theory, management's preference for control and consequent refusal to tender their shares forces acquirers to pay higher premia to gain control when the management's stake is higher, and may lead to an increase in the target firm's 
ex ante value. When the management stake is so large that no takeover can be profitable, however, the ex ante firm value includes no takeover premium, and is therefore low. While Stulz's story differs from Jensen and Meckling's at the lower end of management ownership, it is closely related to the "entrenchment hypothesis" at the higher end.

Because of the nature of our data, this paper has not dealt with several important issues that might be fruitfully pursued in future research. First, we have focused on very large (and therefore usually older) corporations. In newer, faster growing firms, managerial holdings may play a more important signalling role than they are likely to play for our firms. Moreover, as our results have suggested, founders of younger firms might have an important leadership role to play. Research on ownership structure can doubtless benefit from considering smaller firms as well. Second, a better analysis of the impact of officers' stakes on performance would incorporate other compensation data. Important work in this area is Murphy (1985). Finally, on both a theoretical and empirical level, it is very important to learn how members of boards of directors with different individual ownership positions interact, and how the distribution of ownership among board members affects performance. Our work essentially assumed a good deal of unanimity on the board; a more complex story is surely appropriate. 


\section{FOOTNOTES}

1. On-the-job consumption is a generic term that can refer to shirking and taking managerial perquisites, but also encompasses pursuit of non-valuemaximizing objectives such as sales maximization (empire building), clean environment, or the maximization of employee welfare.

2. Numerous studies have shown that control is valued. For example, DeAngelo and DeAngelo (1985) find that, among 45 large corporations with dual classes of common stock entitled to identical cash flows but carrying different voting rights, top managers own a median of $56.9 \%$ of the votes but only $24 \%$ of the common stock cash flows. Loderer and Zimmerman (1985), using Swiss data, find that non-voting issues are priced lower than voting issues.

3. In line with this point, Walkling and Long (1984) find that the larger is the officers' financial gain from a takeover, the less likely they are to resist a bid. At the same time, managerial ownership lessens the firm's vulnerability to a hostile takeover: Weston (1977) reported that no firm where insiders owned over $30 \%$ had ever been acquired through a hostile takeover. 4. The market value of common stock is taken from the standard and Poor's Compustat tape. The market value of preferred stock is estimated by dividing the preferred stock dividend figure (reported in Compustat) by the Moody's preferred dividend rate for median risk companies. The market value of the firm's debt is taken as the value of its short term liabilities net of its short term assets (from Compustat) plus an estimate of the market value of its long term debt. Estimates of long term debt for our firms were obtained from the N.B.E.R.'S R\&D Master File (Cummins, Hall and Laderman, 1982). These estimates are constructed on the assumption that all long term debt has an original maturity of twenty years, and using a matrix of bond prices in year $t$ for bonds 
due in year $s$ from the Moody's corporate BAA bond price series. The age structure of corporate debt is estimated from changes in the firm's book value of long term debt in each of the twenty previous years on the Compustat tape. Using this age structure estimate and the bond price matrix, Cummins et al (1982) calculate the value of each firm's long term debt.

5 We have calculated some descriptive statistics on the sample of 85 firms for which we have ownership data, but do not have market-value-based measures of $Q$ (omitted firms). The mean board stake for these firms is $12.0 \%$ (it is $10.6 \%$ for the sample of 371 firms we study). Among omitted firms, $25 \%$ are run by founding families; among included firms, this number is $24 \%$. From the viewpoint of ownership, therefore, omitted firms do not appear exceptional. As a further check that omission from the sample is not systematic, we calculated the ratio of the replacement cost of the omitted firm to the mean replacement cost in its (3-digit SIC) industry. The average of this ratio among omitted firms is .95. Finally, we calculated the ratio of the book-value-based $Q$ of the omitted firm to the mean book-value-based $Q$ in its (3-digit SIC) industry. The mean of this number for the 51 omitted firms that we can calculate it for is .98. Again, omitted firms do not appear exceptional.

6 Virtually all Fortune 500 firms are listed on the New York Stock Exchange, where listing rules require sufficiently dispersed ownership. This might explain why very few firms in our sample are more than $50 \%$ owned by management. 7. In a previous draft, we also included the value of the firm's unfunded vested pension liabilities. This substantially reduced the sample because of missing data. While the inclusion of this variable "improved" our results, it turned out that it was missing systematically for newer, high Q, relatively high 
board ownership firms, and that the improvement was therefore spurious.

Excluding the pension debt variable thus gives us a larger and less biased sample.

8 For 17 observations, data were not available on the firm's advertising expense either for 1980 or for adjacent years. In those cases, we took the firm's advertising to asset ratio to be the industry average (at the 3 -digit SIC leve1).

9 For each regression, define new board ownership variables by analogy with the way they are defined in the text. The negligible ownership dummy is omitted in each case. Using the same control variables as in equation (1), we obtain the following point estimates and White-consistent standard errors for our sample of 371 firms:

$$
\begin{aligned}
& \mathrm{Q}=\text { control variables }+.165 \cdot \text { BOARD025 }+.298 \cdot \text { BOARD20 }+.164 \cdot \text { BOARD99 } \\
& \begin{array}{lll}
(.0688) & (.0848) & (.0763)
\end{array} \\
& R^{2}=.593 \\
& Q=\text { control variables }+.223 \cdot \text { BOARD075 }+.228 \cdot \text { BOARD20 }+.147 \cdot \text { BOARD99 } \\
& (.0731) \quad(.104) \quad(.0750) \\
& R^{2}=.588 \\
& Q=\text { control variables }+\underset{(.0727)}{.200} \cdot \text { BOARD05 } \underset{(.100)}{.294} \cdot \text { BOARD15 }+\underset{(.0735)}{.172} \cdot \text { BOARD99 } \\
& Q=\text { control variables }+.200 \cdot 80 A R D 05+.237 \cdot \text { BOARD25 }+.203 \cdot \text { BOARD99 } \\
& (.0730) \quad(.0856) \quad(.0911) \\
& R^{2}=.587
\end{aligned}
$$

10 Estimation of equation (1) using $1979 \mathrm{Q}$ and $1981 \mathrm{Q}$ as the dependent variables yields:

$$
\begin{aligned}
& Q_{79}=\text { control variables }+\underset{(.0615)}{.152} \cdot \text { BOARD05 }+\underset{(.0705)}{.255} \cdot \text { BOARD20 }+\underset{(.0692)}{.119} \cdot \text { BOARD99 } \\
& R^{2}=.634 \\
& N=377
\end{aligned}
$$




$$
\begin{aligned}
& -4- \\
& \mathrm{Q}_{81}=\text { control variables }+.167 \cdot \text { BOARD05 }+.205 \cdot \text { BOARD20 }+.138 \cdot \text { BOARD99 } \\
& (.0558) \\
& (.0753) \\
& (.0803) \\
& \mathrm{R}^{2}=.559 \\
& N=370
\end{aligned}
$$

11 . The growth rate in the firm's labor force is a geometric mean of the percent change in its labor force from one year to the next from 1970 to 1980 . For 62 firms, this calculation could not be made. For 59 of those, we set GL equal to the mean rate of growth in the firm's 3-digit sIc industry. Three firms are omitted from the regression because GL could not be imputed in this way. 12. Lewellen (1971) nonetheless reports that top managers get four times as much of their income from ownership income as from other forms of compensation. 13. In a few cases, either only one of the positions of Chairman and President existed for that firm, or the same person occupied both positions. In those cases, the OFFICER variable is the stake of the one top officer. 14. Consistent with this hypothesis, Johnson et al. (1985) find that sudden deaths of chief executives are accompanied by price increases in their firms' stocks when those executives are founders, but not otherwise.

15. We identified the founders and their families using a history of annual reports dating back to either the incorporation of the firm or the turn of the century, whichever was more recent.

16 Year of incorporation is in most cases taken to be the year of the first incorporation of the firm obtained from Moody's Industrial Manuals. In a few cases, Moody's noted a large discrepancy between the year the business was established and the year of first incorporation. The establishment year was used in those cases. 


\section{REFERENCES}

Berle, A. A. Jr. and G. C. Means, The Modern Corporation and Private Property, 1932, New York: MacMillan.

Corporate Data Exchange, Inc., C.D.E. Stock Ownership Directory: Fortune 500, 1981, New York: C.D.E.

Cummins, C., B. Hall, and E. Laderman, 'The R\&D Master File: Documentation', 1982, N.B.E.R. Mimeograph.

De Ange lo, H. and L. De Ange 10, 'Managerial Ownership of Voting Rights: A Study of Public Corporations with Dual Classes of Common Stock', Journal of Financial Economics, 1985, vol. 14, 33-69.

Demsetz, H., 'The Structure of Ownership and the Theory of the Firm', Journal of Law and Economics, 1983, vol. XXVI, 375-390.

Demsetz, H. and K. Lehn, 'The Structure of Corporate Ownership: Causes and Consequences', Journal of Political Economy, December 1985, vol. 93, no. 6 , $1155-1177$.

Fama, E. F., 'Agency Problems and the Theory of the Firm', Journal of Political Economy, April 1980, vol. 88, no. 2, 288-307.

Fama, E. F. and M. C. Jensen, 'Separation of Ownership and Control,' Journal of Law and Economics, June 1983, vol. 26, 301-325.

Hart, O. D., 'The Market Mechanism as an Incentive Scheme,' Bell Journal of Economics, Autumn 1983, vol. 14, 366-382.

Jensen, M. C. and W. H. Meckling, 'Theory of the Firm: Managerial Behavior, Agency Costs and Ownership Structure', Journal of Financial Economics, 1976, vol. 3, 305-360. 
Jensen, M. and R. Ruback, 'The Market for Corporate Control: The Scientific Evidence', Journal of Financial Economics, 1983, vol. XI, 5-50.

Johnson, B., R. Magee, N. Nagarajan and H. Newman, 'An Analys is of the Stock Price Reaction to Sudden Executive Deaths: Implications for the Managerial Labor Market', Journal of Accounting and Economics, April 1985, vol. $7,151-174$.

Leland, M. and D. Pyle, 'Informational Asymmetries, Financial Structure, and Financial Intermediation', Journal of Finance, 1977, vol. 3, no. 2, 371-87. Lewellyn, W., The Ownership Income of Management, 1971, New York: NBER. Lindenberg, E. and S. Ross, Tobin's Q Ratio and Industrial Organization, Journal of Business, 1981, vol. 54, no. 1, 1-32.

Loderer, C. and H. Zimmerman, 'Rights Issues in Switzerland: Some Findings to Consider in the Debate over Financing Decisions,' 1985, Mimeograph. Murphy, K. J., 'Corporate Performance and Managerial Remuneration: An Empirical Analysis,' Journal of Accounting and Economics, April 1985, vol. 7, 11-42. Shleifer, A. and R. W. Vishny, 'Large Shareholders and Corporate Control,' Journal of Political Economy, June 1986, vol. 95, 461-488. Stulz, R.M., 'On Takeover Resistance, Managerial Discretion and Shareholder Wealth', Draft, 1986.

Walkling, R. A. and M. S. Long, 'Agency Theory, Managerial Welfare, and Takeover Bid Resistance,' Rand Journal of Economics, Spring 1984, vol. 15, 54-68. Weston, J. F., 'The Tender Takeover', Mergers and Acquisitions, 1977. White, H., 'A Heteroskedasticity-Consistent Covariance Matrix Estimator and a Direct Test for Heteroskedasticity', Econometrica, May 1980, Vol. 48, 817-838. 
Table 1

Mean values of Tobin's $Q$ for 371 Fortune 500 firms in 1980 grouped by level of equity ownership of the board of directors.

\begin{tabular}{lcll}
\hline $\begin{array}{l}\text { board's } \\
\text { stake }\end{array}$ & $\begin{array}{l}\text { number of } \\
\text { firms }\end{array}$ & $\begin{array}{l}\text { mean } \\
\text { Tobin's } Q\end{array}$ & $\begin{array}{l}\text { standard } \\
\text { error } \\
\text { of mean Q }\end{array}$ \\
\hline negligiblea & 46 & .710 & .0566 \\
$0-5 \%$ & 171 & .879 & .0601 \\
$5-10 \%$ & 38 & .997 & .0948 \\
$10-15 \%$ & 27 & .888 & .129 \\
$15-20 \%$ & 15 & .990 & .205 \\
$20-25 \%$ & 22 & .756 & .0804 \\
$25-30 \%$ & 9 & .588 & .0895 \\
$30-35 \%$ & 6 & .658 & .0990 \\
$35-40 \%$ & 11 & 1.060 & .243 \\
$40-45 \%$ & 6 & .778 & .243 \\
$45-50 \%$ & 6 & .538 & .0991 \\
$50-55 \%$ & 4 & .440 & .0837 \\
$55-60 \%$ & 3 & .428 & .162 \\
$60-65 \%$ & 3 & 1.460 & .568 \\
$65-70 \%$ & 1 & .283 &. \\
$70-75 \%$ & 2 & .489 & -198 \\
$75-80 \%$ & 1 & .937 & - \\
\hline
\end{tabular}

a. Negligible board stake means that no single member of the board of directors owned more than .2\% of the firm's common stock. 
Table 2

Ordinary least squares regressions of corporate performance measures (Tobin's $Q$ and the profit rate) on measures of corporate assets and liabilities, including dummy variables indicating the level of equity




Table 3

T-statistics for the pairwise null hypotheses that the coefficients on the ownership dummy variables estimated in equation (1) are equal.

\begin{tabular}{l|lll}
\hline & & $\begin{array}{l}\text { greater } \\
\text { than 0\% } \\
\text { and not } \\
\text { fractional equity } \\
\text { ownership by the } \\
\text { board of directors } \\
\text { than 5reater } \\
\text { and not } \\
\text { greater } \\
\text { than 20\% }\end{array}$ \\
\hline $\begin{array}{l}\text { greater than 0\% and } \\
\text { not greater than 5\% }\end{array}$ & 2.77 & & \\
$\begin{array}{l}\text { greater than 5\% and } \\
\text { not greater than 20\% }\end{array}$ & 3.06 & .915 & \\
greater than 20\% & 2.06 & .622 & 1.61
\end{tabular}


Table 4

The average values of various measures of firm size for a 1980 sample of 371 fortune 500 firms. The firms are grouped based on the fractional equity ownership of the board of directors.

\begin{tabular}{|c|c|c|c|c|}
\hline $\begin{array}{l}\text { management's } \\
\text { equity stake }\end{array}$ & $\begin{array}{l}\text { number } \\
\text { of firms }\end{array}$ & $\begin{array}{l}\text { mean } \\
\text { replacement } \\
\text { cost of net } \\
\text { assets } a, b\end{array}$ & $\begin{array}{l}\text { mean } \\
\text { market value } \\
\text { of the } \\
\text { firm } a, b\end{array}$ & $\begin{array}{l}\text { mean } \\
\text { market value } \\
\text { of equity } \\
\text { outstanding } a, b\end{array}$ \\
\hline negligible & 46 & $\begin{array}{c}9134 \\
(1798)\end{array}$ & $\begin{array}{c}6795 \\
(1417)\end{array}$ & $\begin{array}{c}5654 \\
(1284)\end{array}$ \\
\hline $0 \%$ to $5 \%$ & 171 & $\begin{array}{l}2194 \\
(246)\end{array}$ & $\begin{array}{l}1705 \\
(195)\end{array}$ & $\begin{array}{l}1407 \\
(176)\end{array}$ \\
\hline $5 \%$ to $10 \%$ & 38 & $\begin{array}{c}992 \\
(163)\end{array}$ & $\begin{array}{c}918 \\
(143)\end{array}$ & $\begin{array}{l}779 \\
(142)\end{array}$ \\
\hline $10 \%$ to $15 \%$ & 27 & $\begin{array}{l}2088 \\
(884)\end{array}$ & $\begin{array}{l}1374 \\
(456)\end{array}$ & $\begin{array}{l}1141 \\
(369)\end{array}$ \\
\hline $15 \%$ to $20 \%$ & 15 & $\begin{array}{l}1215 \\
(393)\end{array}$ & $\begin{array}{l}1043 \\
(341)\end{array}$ & $\begin{array}{c}878 \\
(277)\end{array}$ \\
\hline $20 \%$ to $25 \%$ & 22 & $\begin{array}{l}1693 \\
(422)\end{array}$ & $\begin{array}{l}1287 \\
(334)\end{array}$ & $\begin{array}{l}1005 \\
(247)\end{array}$ \\
\hline $25 \%$ to $30 \%$ & 9 & $\begin{array}{c}564 \\
(116)\end{array}$ & $\begin{array}{l}345 \\
(83)\end{array}$ & $\begin{array}{l}290 \\
(74)\end{array}$ \\
\hline $30 \%$ to $35 \%$ & 6 & $\begin{array}{c}3323 \\
(1825)\end{array}$ & $\begin{array}{c}2177 \\
(1046)\end{array}$ & $\begin{array}{l}1842 \\
(958)\end{array}$ \\
\hline $35 \%$ to $40 \%$ & 11 & $\begin{array}{c}1697 \\
(1029)\end{array}$ & $\begin{array}{l}1741 \\
(886)\end{array}$ & $\begin{array}{l}1409 \\
(647)\end{array}$ \\
\hline $40 \%$ to $45 \%$ & 6 & $\begin{array}{c}4815 \\
(3737)\end{array}$ & $\begin{array}{c}2297 \\
(1334)\end{array}$ & $\begin{array}{l}1136 \\
(402)\end{array}$ \\
\hline $45 \%$ to $50 \%$ & 6 & $\begin{array}{c}798 \\
(220)\end{array}$ & $\begin{array}{l}506 \\
(185)\end{array}$ & $\begin{array}{c}469 \\
(183)\end{array}$ \\
\hline$>50 \%$ & 14 & $\begin{array}{c}458 \\
(118)\end{array}$ & $\begin{array}{l}296 \\
(96)\end{array}$ & $\begin{array}{l}257 \\
(87)\end{array}$ \\
\hline
\end{tabular}

a numbers in brackets are standard errors of the means values are in millions of dollars 
Ordinary least squares regressions of corporate performance measures (Tobin's $Q$ and the profit rate) on measures of corporate assets and liabilities, including dummy variables indicating the level of equity ownership by the firg's top two officers and by the remainder of its board of directors ${ }^{a}, \mathrm{~b}$.

\begin{tabular}{|c|c|c|}
\hline & $Q$ & Q \\
\hline $\begin{array}{l}\text { research and development } \\
\text { per dollar of assets }\end{array}$ & -- & $\begin{array}{l}8.72^{\star \star \star} \\
(2.33)\end{array}$ \\
\hline $\begin{array}{l}\text { advertising expenses } \\
\text { per dollar of assets }\end{array}$ & -- & $\begin{array}{r}-.0315 \\
(.818)\end{array}$ \\
\hline $\begin{array}{l}\text { long term debt } \\
\text { per dollar of assets }\end{array}$ & -- & $\begin{array}{l}-.871^{\star \star} \\
(.374)\end{array}$ \\
\hline $\begin{array}{l}\text { replacement cost } \\
\text { (dollar value of assets) }\end{array}$ & -- & $\begin{array}{l}-.00000278 \\
(.00000378)\end{array}$ \\
\hline $\begin{array}{l}\text { dummy set to one if } 0 \%<\text { stake } \\
\text { of top two officers } \leqslant 5 \%\end{array}$ & $(.0361)$ & $(.0603)$ \\
\hline $\begin{array}{l}\text { dummy set to one if } 5 \%<\text { stake } \\
\text { of top two officers } \leqslant 20 \%\end{array}$ & $\begin{array}{l}.0620 \\
(.122)\end{array}$ & $\begin{array}{l}.0205 \\
(.0997)\end{array}$ \\
\hline $\begin{array}{l}\text { dummy set to one if stake of } \\
\text { top } 2 \text { officers exceeds } 20 \%\end{array}$ & $\begin{array}{r}-.0787 \\
(.102)\end{array}$ & $\begin{array}{l}-.00728 \\
(.0884)\end{array}$ \\
\hline $\begin{array}{l}\text { dummy set to one if } 0 \%<\text { stake } \\
\text { of outside board } \leqslant 5 \%\end{array}$ & $(.0706)$ & $\left(.156^{\star \star}\right.$ \\
\hline $\begin{array}{l}\text { dummy set to one if } 5 \%<\text { stake } \\
\text { of outside board } \leqslant 20 \%\end{array}$ & $\begin{array}{r}.0585 \\
(.107)\end{array}$ & $\left(.234^{\star \star}\right.$ \\
\hline $\begin{array}{l}\text { dummy set to one if stake of } \\
\text { outside board exceeds } 20 \%\end{array}$ & -.0886 & $\left(.171^{\star}\right.$ \\
\hline $\begin{array}{l}\text { industry dummies for } \\
3 \text { digit SIC codes }\end{array}$ & $\begin{array}{l}\text { not } \\
\text { included }\end{array}$ & included \\
\hline number of observations & 371 & 371 \\
\hline$R^{2}$ & .008 & .591 \\
\hline
\end{tabular}

a $\star=$ significant at $90 \%$ confidence level

$\star \star=$ significant at $95 \%$ confidence level $\star \star \star=$ significant at $99 \%$ confidence leve 1

${ }^{b}$ Numbers in brackets are consistent standard errors calculated according to White (1980). 